\title{
Activities Written by Prospective Primary Teachers on Realistic Mathematics Education
}

\author{
Hatice Kubra Guler \\ Departement of Elementary Mathematics Education, Duzce University
}

\begin{tabular}{l}
\hline \hline Article Info \\
\hline Article history: \\
Received Jul 11, 2018 \\
Revised Aug 7, 2018 \\
Accepted Aug 20, 2018 \\
\hline
\end{tabular}

Keyword:

Prospective Primary Teachers

Realistic Mathematics

Education (RME)

Teaching And Learning

Activity

\begin{abstract}
It is important for students to connect with real life in mathematics courses. The aim of this study is to investigate the activities which are written by prospective primary school teachers in the context of Realistic Mathematics Education. This research is a case study of which data were collected by qualitative methods. The participants of the research included 81 prospective primary teachers who are junior students attended primary teacher department. It was asked them to write an activity suitable for primary mathematics curriculum by considering Realistic Mathematics Education principles. They were given one month to write the activities. The activities written by prospective teachers analyzed by descriptive methods in terms of learning domains, types of context and principles of Realistic Mathematics Education. Totally 36 activities were written by prospective teachers. Based on the analysis, it was observed that not all the contexts were exactly real life contexts. It was determined that prospective teacher could not distinguish routine word problems from real life problems. It can be said that theoretical knowledge of Realistic Mathematics Education is inadequate for writing activities and prospective primary teachers need to practice on writing activities regarding the mentioned theory.
\end{abstract}

Copyright $\left({ }_{0} 2018\right.$ Institute of Advanced Engineering and Science. All rights reserved.

\section{Corresponding Author:}

Hatice Kubra Güler,

Departement of Elementary Mathematics Education,

Duzce University,

Konuralp Campus 81620 Duzce/Turkey

Email: haticeguler@duzce.edu.tr

\section{INTRODUCTION}

Recently, the opinions are shared and researches are carried out regarding the fact that education should be practical and related to real life [1]. The mentioned situation goes for mathematics; because of that mathematics is abstraction of the real life. Therefore, it is important for students to connect with real life in mathematics courses [2], [3]. Realistic Mathematics Education (RME) is a unique theory used in mathematics education, which was put forward by Hans Freudenthal to relate mathematics with real life. In this theory, it is worked on the circumstances in real life, or possible happening in real life conditions.

Constructing mathematical knowledge was called mathematization by Freudenthal who developed RME. Mathematization is divided into two by horizontal and vertical mathematization. At horizontal mathematization, students start activity with a real context problems and then they use informal language and symbols to define problems. At this level, every student can discover a different solution way. As for vertical mathematization, at this level, students start to work with mathematical symbols and they can reach formulas by establishing relationship among the concepts [4]. Freudenthal defined horizontal mathematization as transforming real contexts to symbols while vertical mathematization as moving in symbols/mathematics world. Knowledge is constructed while studying on real context problems and then the constructed 
knowledge become a mathematical form after mathematization. After that, it can be used in exercise and further activities to construct new knowledge.

In the process of constructing mathematical knowledge, there are three key principles. Gravemeijer [4] stated that they were didactic phenomenology, guided discovery and inclusion of models. The main question is how the suitable didactical structures of mathematics subjects can be established for the relevant age group. This is not only about the definition of the mathematical concepts but also establishing the relationship between real context and mathematical world. According to didactical phenomenology, the mathematical activities should start with the knowledge which is meaningful for students. This is supported the learning process. Didactical phenomenology explains how a mathematical concept is constructed by analyzing them. According to guided discovery, students should have the opportunity to try a method or study similar to the invention of mathematics. Guided discovery can be implemented through informal knowledge. Informal knowledge and strategies can be used as a way to formal strategies. Considering inclusion of models, students should be able to create their own models when solving problems. Firstly, students develop a model that they are familiar with their own informal knowledge. The model which was developed after the generalization and formalization process became a stand-alone structure gradually. This process is called "the model transition process". After this transition, the model can be used as a formal mathematical model. In RME, constructing formal model is the ultimate goal. So, it should not be started with formal knowledge, which is the ultimate goal of the mathematics teaching [4].

In RME, context problems are the basis for the mathematical process. The context problems lead students to discover the knowledge and enable them to reach formal mathematical models [5]. The problem should allow the horizontal and vertical mathematization process as needed for exploration. The teachers' main question should be "how can I discover this?". First of all, students are given problems that they can develop specific methods for the situation. If the student can create new methods to solve problem, their methods become models. In other words, models are developed with the activities of the students. Another criterion is that the model allows students to do vertical mathematics [6].

Gravemeijer [7] discussed the role of models developed during the formal mathematical process in his work. The underlined philosophy of his study was that mathematization was a work done by students. In this paper, it was mentioned how the models was explained more and how the models were developed over time. A course which dealt with mental calculation strategies and addition up to 100 was designed. Analyses were revealed three related process. First one was that the models were initially products of informal mathematical activities, but later they were developed by formal mathematical activities. The second one involved the construction of new mathematical truths with formal relations by transforming model of to model for. Thirdly, it was seen that there were more than one model that could be created at the end of activities.

Some researchers were showed that using RME theory in mathematic classes improved students' mathematic successes [8]-[12] and it enables for them to internalize the concepts deeply [13]-[16]. Kwon [17] used the mentioned theory for undergraduate students in diferential equantions courses. It was founded at the end of the study that students' abitility of modelling improved. Gravemeijer and Doorman [5] discussed using RME theory for students in order to reach formal mathematicsl models. They prepared a calculus course using RME and focused on modelling. The aim of their study was reaching model for stage. Van den Heuvel-Panhuizen [10] worked on RME and defined it as a model which enabled for students to improve their mathematical thinking. He suggested line graphic as a strong model for percentages subject in mathematics.

Models are important in the mathematics learning and teaching process both earlier and upper ages. Treffers [18] suggested that the empty number line as an effective model in order to teach number line in early ages. As Treffers, Altun [19] studied on teaching number line by the help of RME. In his study, it was suggested that "apple stair-model" could be used for teaching number line in early ages.

Considering that students are at concrete operational stage, RME activities applicable for primary schools should be developed for students to learn mathematics well. Zulkardi [20] arranged a project taking four years and trained prospective teacher on RME. In this comprehensive research, it was found that prospective mathematics teachers learnt philosophy of RME and they could write activities on RME. As seen, not only important issue is using RME activities in classes but also it is important for teacher to design an environment suitable for RME and to write activies according to the mentioned theory. It is really difficult for teachers to find activities suitable for RME; it is because there are few RME activities in textbooks, literature and etc. Also, teacher couldn't use an activity near at hand because of that the students' prior knowledge, area of residence and etc. As seen, the earlier studies are generally mentioned how RME could be used in classes and whether it was really improved students mathematics achievements. Therefore, the aim of this study is to investigate the activities which are written by prospective primary school teachers in the

IJERE Vol. 7, No. 3, September 2018: $229-235$ 
context of RME. The main question of the research is whether theoretical knowledge of RME is adequate for writing RME activities or not.

\section{RESEARCH METHOD}

This research is a case study of which data were collected by qualitative methods. The participants of the research included 81 prospective primary teachers who were junior students attended primary teacher department. The participants took the mathematics education course and they had the theoretical knowledge regarding RME. The theory and its principles were explained by using two different RME activities named "Snakes" and "What didn't the king know?". The aim of the "snakes" problem was for students to construct geometric sets while the aim of the "what didn't king know?" was to be constructed geometric series. And also in the courses, Bloom's taxonomy was compared with RME in terms of horizontal a vertical mathematization. The following Figure 1 was given students and it was discussed in the class in terms of Bloom's taxonomy and RME.

\begin{tabular}{cl}
\multicolumn{1}{c}{ Horizontal } & Knowledge \\
Mathematization & Comprehension \\
& Application \\
& Analysis \\
& Synthesis \\
& Evaluation
\end{tabular}

Figure 1. Horizontal and vertical mathematization

It was explained students that horizontal mathematization started with application, as seen from Figure 1. After constructing knowledge, vertical mathematization continues as Bloom's taxonomoy. In the following courses, the priciniples of active learning was explained and related with RME. Activities which were carried out during the course were investigated in terms of the principles of active learning and RME.

The participants were provided an option to set up groups of maximum three people if they wanted to. They grouped 12 groups consisting of three students and 21 groups consisting of two students. Three students preferred to write activities alone. It was asked each group to write an activity suitable for primary mathematics curriculum by considering RME principles. They were given one month to write the activities. The activities written by prospective teachers analyzed by descriptive methods in terms of learning domains (numbers, geometry, measurement, and, data and statistics), types of context (scientific, public, personal, and occupational) and principles of RME (guided reinvention, didactical phenomenology, and inclusion of models). In addition, it was discussed with prospective teachers on activities written by them in a whole class discussion.

In the analyses which were done according to the principles of RME, the following criteria were considered:

1) Did the problems/activities which were written by prospective teachers have a familiar context for students?

2) Did the problems/activities which were written by prospective teachers have the characteristics of the real context?

3) Did the problems/activities which were written by prospective teachers enable students to develop different problem solving strategies and to do explanations by using informal language?

4) Did the solution of the problems enable to use physical models?

5) At the end of the activities, could it be constructed a structure which could use solving another problem or could it be made a generalization?

The first three criteria are regarding "guided reinvention" and "didactical phenomenology". The fourth and fifth ones are regarding "inclusion of models".

\section{RESULTS AND ANALYSIS}

Totally 36 activities were written by prospective teachers. One of them was excluded from the analysis because it was related to arithmetic sequence; which wasn't a primary mathematics subject. Out of

Written by Prospective Primary Teachers on Realistic Mathematics Education (Hatice Kubra Guler) 
35 activities, 16 of them were regarding numbers, 16 of them were regarding measurement, and 3 of them were regarding geometry learning domain. There were not any activities regarding data and statistics learning domain. The subjects of the activites are measurement of area, fractions, decimal numbers, patterns, division, symmetry, perimeter of rectangle, measurement of liquids and etc.

Although some of the activities had the game features, all contexts were personal. Especially the contexts of the activities regarding numbers learning domain were quite closed to routine problems in the textbooks.

As for RME principles, it can be analysed domain by domain. The familiarity of the contexts was given in Table 1.

Table 1. Familiarity of the contexts

\begin{tabular}{ccccc}
\hline Learning Domains & Not familiar & Partially familiar & Familiar & Total \\
\hline Numbers & 3 & 0 & 13 & 16 \\
Measurement & 0 & 3 & 13 & 16 \\
Geometry & 0 & 0 & 3 & 3 \\
Total & 3 & 3 & 29 & 35 \\
\hline
\end{tabular}

As seen from Table 1, 29 of the contexts were familiar for primary students. From the familiar activities 13 of them were regarding numbers, 13 of them were regarding measurent and 3 of them were regarding geometry. From Table 1 it can be said that the activities written by prospective teachers were familiar for primary students. But not all the familiar contexts were real life situations. It can be seen from Table 2.

Table 2. Number of real context problems

\begin{tabular}{ccccc}
\hline Learning Domains & $\begin{array}{c}\text { Not real context } \\
\text { problem }\end{array}$ & $\begin{array}{c}\text { Partially real context } \\
\text { problem }\end{array}$ & $\begin{array}{c}\text { Real context } \\
\text { problem }\end{array}$ & Total \\
\hline Numbers & 5 & 3 & 8 & 16 \\
Measurement & 2 & 8 & 6 & 16 \\
Geometry & 1 & 1 & 1 & 3 \\
Total & 8 & 12 & 15 & 35 \\
\hline
\end{tabular}

As seen from Table 2, 15 of the written activities were real context problem. And only 8 of 16 contexts regarding numbers were real context problems while 6 of 16 contexts regarding measurement were real situations. As for geometry, only one of them had characteristic of real problem. From this result it can be said that prospective teachers had difficulty in writing real context problems regarding geometry subjects.

"Partially real context problem" means that the routine problems which were found in textbooks were written in contexts. From Table 2, it can be said that nearly half of the contexts were real context problems. As for strategies which were problems needed and enabled students to do explanations in informal language, the results can be seen from Table 3.

Table 3. Number of the used strategies

\begin{tabular}{ccccc}
\hline Learning Domains & $\begin{array}{c}\text { Only one routine } \\
\text { strategy }\end{array}$ & $\begin{array}{c}\text { More than one but } \\
\text { routine strategies }\end{array}$ & $\begin{array}{c}\text { Non-routine } \\
\text { strategies }\end{array}$ & Total \\
\hline Numbers & 8 & 1 & 7 & 16 \\
Measurement & 6 & 4 & 6 & 16 \\
Geometry & 1 & 1 & 1 & 3 \\
Total & 15 & 6 & 14 & 35 \\
\hline
\end{tabular}

Totally 14 of the activities enabled students to explain their solution ways informally and their problem solving strategies could be non-routine strategies. 15 of the activities were routine problems and they didn't have the charachteristics which enabled students to explain their solution informally; it was because they only required alghoritmic operations. From Table 3, it can be said that less than half of the contexts required non-routine strategies. 
Table 4. Enabling to use physical models

\begin{tabular}{ccccc}
\hline Learning Domains & Not to enable & Optional & To enable & Total \\
\hline Numbers & 6 & 1 & 9 & 16 \\
Measurement & 2 & 4 & 10 & 16 \\
Geometry & 1 & 0 & 2 & 3 \\
Total & 9 & 5 & 21 & 35 \\
\hline
\end{tabular}

From Table 4, it can be seen how many problems' solutions enable to use physical models. 9 of the written activities didn't require to use physical models while, 21 of them required to use. Only in 5 activities, physical model using was optional. The problems could solve with concrete materials or without. Both of them were possible. But more than half of them enabled to use concrete materials to solve problem. But it was really interesting that only 11 activities gave the opportunity students to move from physical model to mathematical model and to make generalization. It can be seen from Tablo 5.

When the written activities are examined, it was seen that most of them supported the use of concrete materials even though they were not real context problems. Many of them were like games and because of that reason it can be said that they required using physical models. While they required physical models, they didn't give opportunity to move mathematical models.

Table 5. Enabling to make generalization

\begin{tabular}{ccccc}
\hline Learning Domains & Not to enable & Optional & To enable & Total \\
\hline Numbers & 9 & 3 & 4 & 16 \\
Measurement & 6 & 4 & 6 & 16 \\
Geometry & 1 & 1 & 1 & 3 \\
Total & 16 & 8 & 11 & 35 \\
\hline
\end{tabular}

As seen Table 5, 16 of the written activities didn't give opportunity students to make generilazations and develop mathematical models. In 8 of the written activities, making generalization depended on teachers. How the teacher guided the students during the activity was an indication that they would develop or not develop their mathematical models. If the teacher carried out the activities as in a traditional and teachercentered class, it was taken from the possibilities of generalization of the students.

In the interviews, participants stated that they had difficulty in carrying out the principle of "inclusion of models". The data which presented in tables confirmed their statements. The data wshowed that they didn't have difficulty in considering "guided reinvention" and "didactical phenomenology" when compared with "inclusion of models".

Also, an interesting datum was that an activity was quite similar with Treffers' [18] and Altun's [19] activities which were "empty number line" and "apple stairs". Their activity was related to number line and they used apple stairs to construct number line. Prospective teachers' drawings about the problem can be seen in Figure 2.
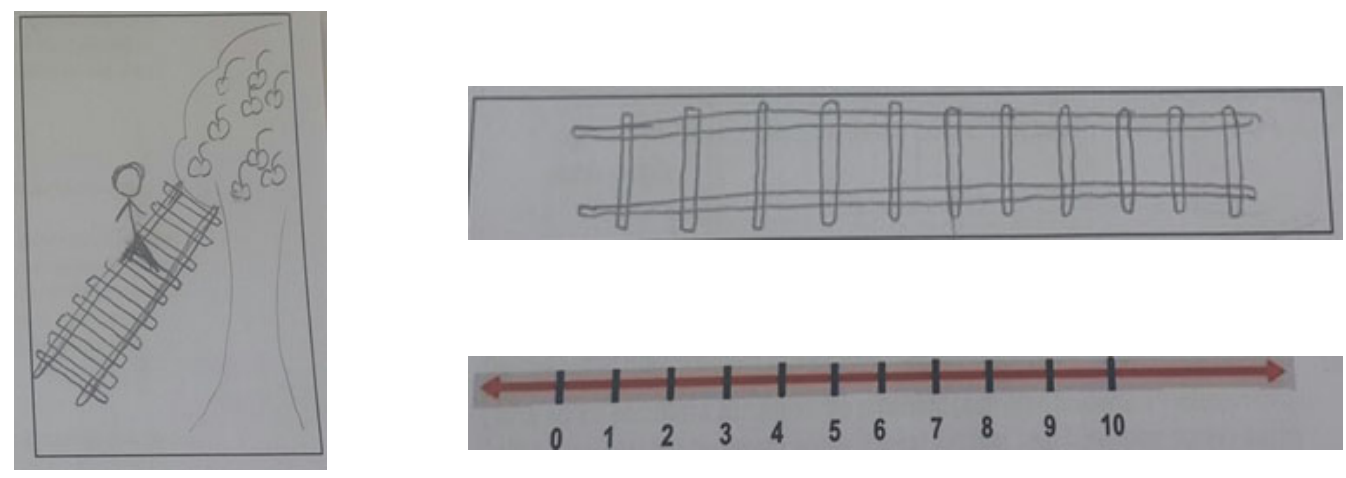

Figure 2. Apple stairs problem written by prospective teachers

As seen from the Figure 2, prospective teachers drew an apple stairs. Then they tilted it and after that they simulated it to a number line. In this way, they aimed for primary students to construct number line

Written by Prospective Primary Teachers on Realistic Mathematics Education (Hatice Kubra Guler) 
knowledge by using RME. When had an interview with prospective teachers who wrote the activity, they stated that they had never seen seen Treffer's article; while they saw Altun's article after they had prepared the activity. And their activity had all three principles of RME.

\section{DISCUSSION AND IMPLICATIONS}

Gravemeijer [4] stated that there were three key principles in the process of constructing mathematical knowledge and they were didactic phenomenology, guided discovery and inclusion of models. Earlier researches [4]-[7], [11] emphasized the importance of "inclusion of models" in RME. When investigating from the view point of the principles of Realistic Mathematics Education, activities which were written in the current study moderately had the features of guided reinvention and didactical phenomenology, although they did not have the features of inclusion of models adequately. This situation was stated by prospective teacher in the interview. They had difficulty in giving oppurtunities students to transform the informal models into formal ones. From this result, it can be suggested that prospectives primary teachers need mathematical modelling activities.

Mathematization process has two steps: horizontal and vertical [4]. Horizontal mathematization starts with a problem (an application) and it finishes with constructing the knowledge in other words with informal model. After that verical mathematization starts and finishes with formal model. Because to be completed the RME activity and mathematization process, students should make a generilazation and construct the mathematical models which can use for solving other problems. According to principles which were stated by Gravemeijer [4], the activities weren't suitable for completing mathematization process in the current reseach. From this result, it can be suggested that prospectives primary teachers need to do and prepare activities both horizontal and vertical mathematization; it is because this situation directly affects that students use and construct formal models.

One group wrote an activity quite similar to Treffer's [18] and Altun's [19] problems without meeting them. This group really motivated and they were interested in mathematics teaching. This situation showed that if prospective primary teachers motivated, they could prepare acvities suitable for RME.

Zulkardi [20] stated that the prospective teachers in his study learnt RME's philosophy and could write activities regarding it. But in the current study, it can be said that although prospective teachers learnt the mentioned theory, they had difficulties on writing activities on it. When the written activities were examined, even if the activity had the real context problem characteristics, teachers could take it as a routine problem. So, while activities are carrying out, teachers have too many tasks. They should be an effective guide for students, only in this way activities could be carried out as a RME activity. Otherwise, the activity is condemned to be a routine problem. So, teachers should know and use the pricinciples of RME well.

\section{CONCLUSION}

The aim of this research was to investigate whether theoretical knowledge of RME was adequate for writing RME activities or not. Totally 36 activities were written by prospective teachers. One of them was excluded from the analysis because it wasn't a subject of primary mathematics. All the written contexts were personal. It was asked participants to start preparing activities with a context problem. However, based on the analysis, it was observed that not all the contexts were exactly real life contexts. It was determined that prospective teacher could not distinguish routine word problems from real life problems. The activities written by prospective teachers were familiar for primary students. Nearly half of the contexts were real context problems. Less than half of the contexts required non-routine strategies. Generally routine strategies were enough to solve the problems. But this isn't enough for RME. In RME, it is expected students to explain situations informally and use non-routine problem solving strategies.

Half of the written activities enabled to use concrete materials to solve problem. Many of them were like games and because of that reason it can be said that they required using physical models. While they required physical models, they didn't give opportunity to move mathematical models.

Considering the view point of learning domains, it was seen that they wrote contexts including numeric operations. Activities for conceptual learning were not written. For example, geometry subjects give students oppurtunities using concrete materials when compared with other domains like numbers, arithmetic and etc. It was expected for prospective teachers to write more than one activity on geometry subjects. But they only wrote 3 activities regarding that issue; in addition only one of them had real context problem characteristic.

According to all the findings of this study, it can be said that theoretical knowledge of Realistic Mathematics Education was inadequate for writing RME activities. Although some of the written activities 
were suitable for the theory, prospective primary teachers needed to practice on writing activities regarding the mentioned theory.

\section{REFERENCES}

[1] Organisation for Economic Co-operation and Development (OECD). "PISA 2015 assessment and analytical framework: science, reading, mathematic and financial literacy". OECD publishing, 2016.

[2] National Council of Teachers of Mathematics (NCTM). "Principles and standards for school mathematics". Reston, Va.: NCTM, 2000

[3] Cotton, T. "Mathematics teaching in the real world." Issues in mathematics teaching. Routledge, Pp. 39-53, 2002.

[4] Gravemeijer, K. "Developing realistic mathematics education,” Freudenthal Institute, Utrech, 1994.

[5] Gravemeijer, K. and Doorman, M. "Context problems in realistic mathematics education: A calculus course as an example." Educational studies in mathematics 39(1-3). Pp. 111-129, 1999.

[6] Gravemeijer, K. \& Doorman, M. "Context problems in realistic mathematics education: A calculus course as an example," Educational Studies in Mathematics, vol/issue: 39(1-3). Pp. 111-129, 1999.

[7] Gravemeijer, K. "How emergent models may foster the constitution of formal mathematics," Mathematical Thinking and Learning, vol/issue: 1(2), 155-177, 1999.

[8] Çilingir, E. "The effect of the realistic mathematic education (rme) approach on visual math literacy self efficacy perceptions and problem solving achievement of 4th grade students", Unpublished master thesis, Çukurova University: Adana, 2015.

[9] Özkaya, A. "The effects of realistic mathematics education on student's achivements, attitudes and self reports in 5th grades mathematics lesson", Unpublished master thesis, Gazi University: Ankara, 2016.

[10] Van Dijk, I. M. A. W., et al. "Strategic learning in primary mathematics education: Effects of an experimental program in modelling," Educational Research and Evaluation, vol/issue: 9(2). Pp. 161-187, 2003.

[11] Van den Heuvel-Panhuizen, M. "The didactical use of models in realistic mathematics education: An example from a longitudinal trajectory on percentage," Educational Studies in Mathematics, vol/issue: 54(1). Pp. 9-35, 2003.

[12] Kurt, E. S. Gerçekçi matematik eğitiminin uzunluk ölçme konusunda başarı ve kalıcllı̆ga etkisi. Unpublished master thesis, Ondokuz Mayıs University: Samsun, 2015.

[13] Fauzan, A. Applying realistic mathematics education (RME) in teaching geometry in Endonesian primary schools. Doctoral dissertation, University of Twente: Enschede, 2002.

[14] Bonotto, C. How informal out-of-school mathematics can help students make sense of formal in-school mathematics: the case of multiplying by decimal numbers. Mathematical Thinking \& Learning, 7(4). Pp. 313-344, 2005.

[15] Tunalı, Ö. K. Açı kavramının gerçekçi matematik öğretimi ve yapılandırmacı kurama göre öğretiminin karşılaştırılması. Unpublished master thesis, Uludağ University: Bursa, 2010.

[16] Uça, S. Öğrencilerin ondalık kesirleri anlamlandırmasında gerçekçi matematik eğitimi kullanımı: bir tasarı araştırmast. Unpublished master thesis, Adnan Menderes University: Aydın, 2014.

[17] Kwon, P. "Hope, defense mechanisms, and adjustment: Implications for false hope and defensive hopelessness," Journal of Personality, vol/issue: 70(2). Pp. 207-231, 2002.

[18] Treffers, A. "Meeting innumeracy at primary school," Educational Studies in Mathematics, vol/issue: 22(4). Pp. 333-352, 1991

[19] Altun, M. "Sayı doğrusunun öğretiminde yeni bir yaklaşım,” İlköğretim Online, vol/issue: 1(2). Pp. 33-39, 2002.

[20] Zulkardi, Z. Developing a learning environment on realistic mathematics education for Indonesian student teachers. Doctoral Dissertation, Univesity of Twente: Enschede, 2002.

\section{BIBLIOGRAPHY OF AUTHOR}

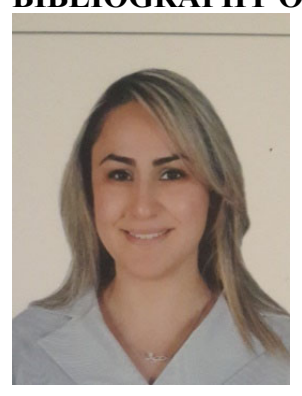

Assist. Prof. Dr. Hatice Kübra Güler is completed her BA Degree at Dokuz Eylul University, Buca Faculty of Education, Elemantary Mathematics Education Program and completed her MA Degree at Gazi University on the same program. She took her PhD Degrees at Uludag University, Elementary Education Program. She had been at Siena University for six months as a $\mathrm{PhD}$ student by the help of ERASMUS Student Exchange Program. Her research interests are mathematics teacher training, mathematical literacy, effective mathematics teaching, geometry teaching and mathematical abstraction. 